Nat. Hazards Earth Syst. Sci., 18, 921-934, 2018

https://doi.org/10.5194/nhess-18-921-2018

(c) Author(s) 2018. This work is distributed under the Creative Commons Attribution 4.0 License.

\title{
Damage during the 6-24 February 2017 Ayvacık (Çanakkale) earthquake swarm
}

\author{
Ramazan Livaoğlu ${ }^{1}$, Mehmet Ömer Timurağaoğlu ${ }^{1}$, Cavit Serhatoğlu ${ }^{1}$, and Mahmud Sami Döven ${ }^{2}$ \\ ${ }^{1}$ Department of Civil Engineering, Engineering Faculty, Uludağ University, Bursa, Turkey \\ ${ }^{2}$ Department of Civil Engineering, Engineering Faculty, Dumlupinar University, Kütahya, Turkey
}

Correspondence: Ramazan Livaoğlu (rliva@uludag.edu.tr)

Received: 3 July 2017 - Discussion started: 26 July 2017

Revised: 26 January 2018 - Accepted: 7 February 2018 - Published: 23 March 2018

\begin{abstract}
On 6 February 2017 an earthquake swarm began at the western end of Turkey. This was the first recorded swarm in the Çanakkale region since continuous seismic monitoring began in 1970. The number of earthquakes located increased during the following 10 days. This paper describes the output of a survey carried out in the earthquake-prone towns in the area of Ayvacık, Çanakkale, Turkey, in February 2017 after the earthquakes. Observations of traditional buildings were made on site at the rural area of Ayvacık. A description of the main structural features and their effects on the most frequently viewed damage modes were made according to in-plane, out-of-plane behavior of the wall regarding construction practice, connection type, etc. It was found that there were no convenient connections like cavity ties or sufficient mortar strength resulting in decreased and/or lack of lateral load bearing capacity of the wall. Furthermore, distribution maps of damaged/undamaged buildings according to villages, damage ratios, structures and damage levels are generated. Distribution maps showed that damage ratio of structures is higher in villages close to epicenter and decrease away from epicenter except Gülpınar, where past experiences and development level affect the construction quality.
\end{abstract}

\section{Introduction}

On 6 February 2017, a swarm of earthquakes began at the western end of Turkey at 06:51 local time. This was the first recorded swarm in this region of Turkey since continuous seismic monitoring began in 1970. The number of earthquakes located increased during the following 10 days and earthquakes bigger than $M_{\mathrm{w}}=5.0$ were experienced 5 times (Table 1). These data were taken from DEMP (Disaster and Emergency Management Presidency) report. The largest peaks from these medium-sized earthquakes occurred twice $\left(M_{\mathrm{w}}=5.3\right)$ at different local times on 6 February 2017 at a depth of 7 and $9.83 \mathrm{~km}$, respectively (Table 1). The earthquakes and aftershocks that took place in this area between 6 and 24 February 2017 are shown in Fig. 1a. A total of 1930 earthquakes $(M>2.0)$ occurred until 24 February. The distribution of the epicenters of the events and their magnitudes provided the earthquake swarm characteristics. Figure 2 shows the evidence of the swarm. This graph depicts distribution of both magnitude vs. occurrence date and magnitude vs. cumulative number of earthquakes over time between 6 and 16 February.

According to the active fault map prepared by MRE (General Directorate of Mineral Research and Exploration), these earthquakes occurred as strike-slip normal fault in the region near the Tuzla segment of Kestanbol fault and Gülpınar fault (Fig. 1b). There were five villages which were closer than $5 \mathrm{~km}$ to the epicenter of the earthquakes. Around 30 villages were struck by the earthquakes, which damaged nearly 2600 structures, and fortunately there were no casualties. The county center, where there was no loss of life and almost no critical damage, is approximately $15-20 \mathrm{~km}$ from the epicenters of the earthquakes.

In Turkey, there are many different construction styles for supporting systems. More than $90 \%$ of these are reinforced concrete in city centers. Also, traditional rural domestic supporting systems are very distinctive, resulting from cultural attributes related to the availability of material and to climate conditions at the building site. Timber is also one of the main materials preferred in building framed houses, es- 
Table 1. Parameters of Ayvacık (Çanakkale) earthquakes (DEMP, 2017).

\begin{tabular}{lrrrrrr}
\hline \multicolumn{1}{l}{ Date } & Local time & Latitude & Longitude & Depth $(\mathrm{km})$ & Magnitude $\left(M_{\mathrm{L}, \mathrm{W}}\right)$ & Max acc.-PGA $(g)$ \\
\hline 06.02 .2017 & $06: 51$ & 39.5495 & 26.1370 & 14.12 & 5.3 & $0.078(\mathrm{~N}-\mathrm{S})$ \\
06.02 .2017 & $13: 58$ & 39.5303 & 26.1351 & 8.70 & 5.3 & $0.103(\mathrm{~N}-\mathrm{S})$ \\
07.02 .2017 & $05: 24$ & 39.5205 & 26.1570 & 6.24 & 5.2 & $0.090(\mathrm{E}-\mathrm{W})$ \\
10.02 .2017 & $11: 55$ & 39.5236 & 26.1946 & 7.01 & 5.0 & $0.038(\mathrm{~N}-\mathrm{S})$ \\
12.02 .2017 & $16: 48$ & 39.5336 & 26.1700 & 7.00 & 5.3 & $0.089(\mathrm{E}-\mathrm{W})$ \\
\hline
\end{tabular}
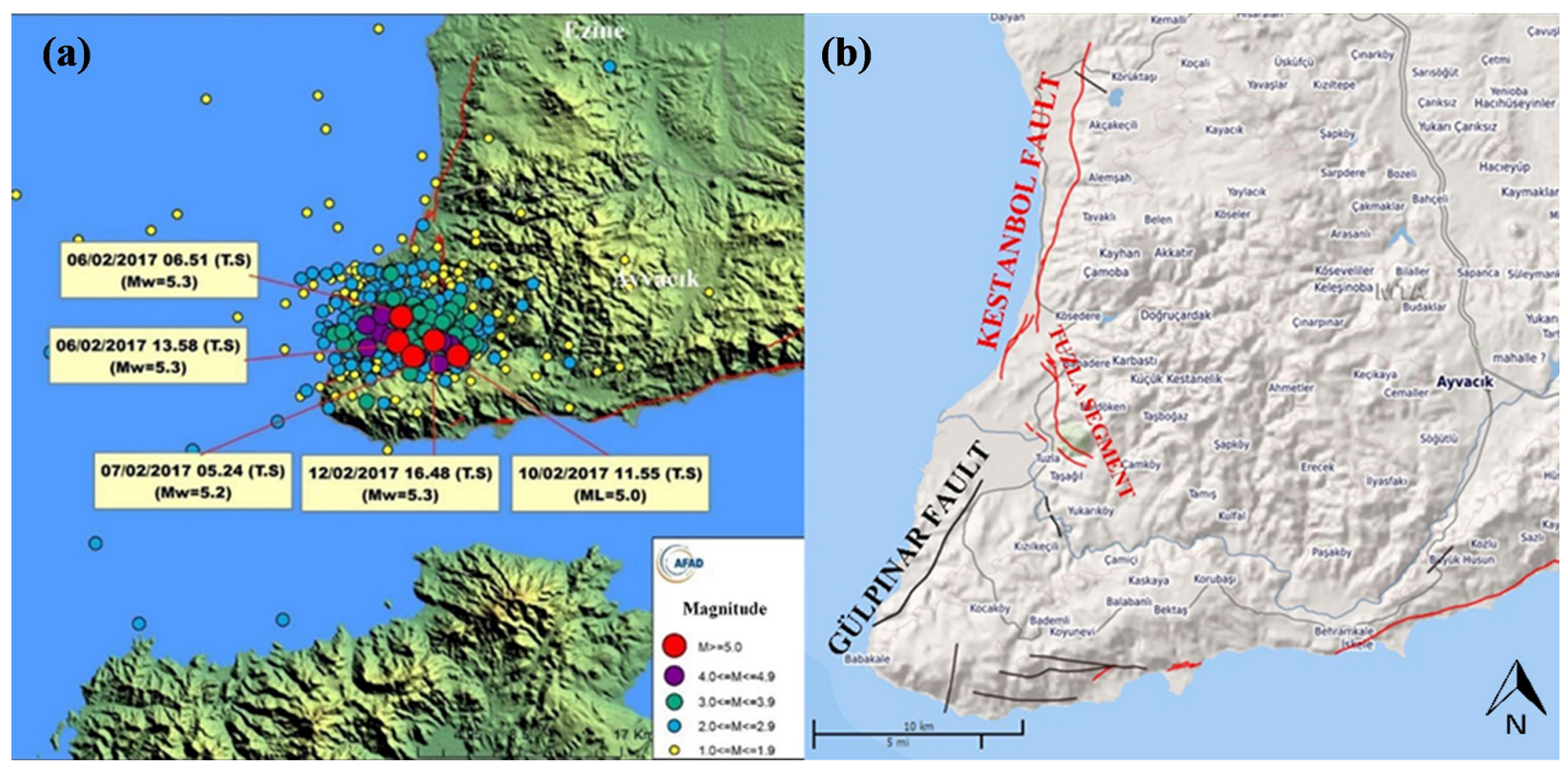

Figure 1. (a) The 6-24 February 2017 Ayvacık (Çanakkale) earthquakes and aftershocks (DEMP, 2017) (b) Active fault map for Ayvacık, Çanakkale (Emre et al., 2013).

pecially in the Black Sea region of Turkey and in other hillside/mountainside regions where timber is abundant. In any case, stone is a material that can be easily found, and lack of timber leaves people no choice but to use more stone in construction details. However, stone is not a suitable material in earthquake-prone areas, because of its unit weight and being difficult to process. Timber also has an extensive history as a main structural reinforcing element known as hattl in rubble stone, brick and adobe houses, the predominant types of houses for ordinary people especially in rural areas (Fig. 3; Hughes, 2000).

In the reconnaissance area, observations showed that construction materials and skills were extremely deficient. Modern materials and techniques were only used in a small portion of the observed region. Moreover, cement mortar between stones was not used in almost $50 \%$ of the walls. There were a few buildings in which reinforced concrete elements were partly or fully used. Curing of concrete is still not practiced as an integral part of the concreting process. The concrete blocks are of poor quality because of the lack of com- paction and very little or no curing. The existing building types in the area are shown in Fig. 4.

A field reconnaissance was carried out by four authors immediately after the earthquakes on 12-17 February, for a period of 5 days, and the observations were reported in the present paper. The authors also experienced the $M_{\mathrm{w}}=5.3$ earthquake on 12 February during their observations. The objective of field reconnaissance was to record the causes of the damage patterns observed in the buildings, mainly in the rural areas affected by the earthquake swarm. The paper discusses the seismological aspects of the earthquakes, describes the classifications of buildings in the area, elaborates on the performance of various building types during the earthquakes and evaluates the damage distributions according to villages, damage ratios, structures and damage levels.

\section{Seismicity of the region}

Turkey is an earthquake-prone country which is located on seismically active regions in the Alpine-Himalayan belt, and its complex deformation is a result of the continental colli- 

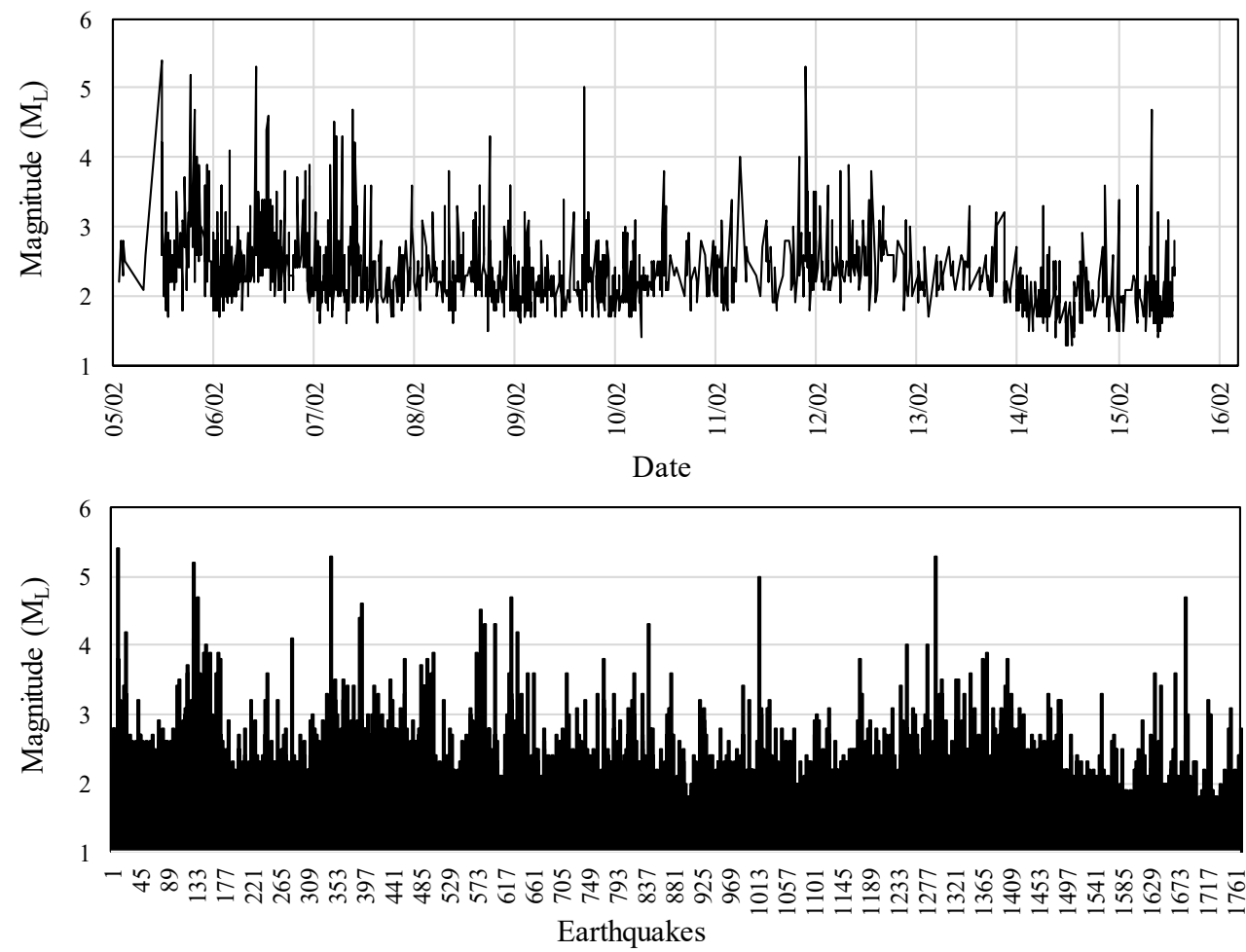

Figure 2. Distribution of the 6-16 February Ayvacık (Çanakkale) earthquake swarm by date and cumulative number up to related date.
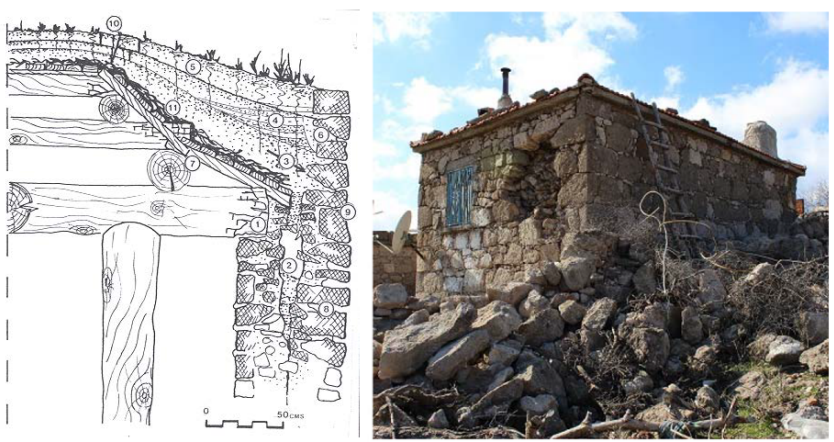

Figure 3. Typical wall construction detail (Hughes, 2000) and typical view of a dwelling from the region.

sion between African and Eurasian plates (Fig. 5a). The major neotectonic elements of the region are the dextral North Anatolian fault zone (NAFZ), the sinistral East Anatolian fault zone (EAFZ) and the Aegean-Cyprus Arc, which forms a convergent plate boundary between the Afro-Arabian and Anatolian plates (Gürer and Bayrak, 2017). The geological events in the region such as plate motions, seismic activities and crustal deformations are attributed to these major neotectonic entities (Bozkurt, 2001).

In this study, the region of northwest Anatolia has been investigated from both land and sea. This region is one of the most important active seismic and deformation regions between Eurasian and African tectonic plates. The region is affected by both the strike-slip tectonic regime, which is a general characteristic of NAFZ, and the extensional regime of west Anatolian block. The most powerful earthquakes within the instrumental period (after 1900) around the region are the Aegean Sea earthquake $(M=7.2)$ that occurred in 1981, Ayvacık (Çanakkale) earthquake $(M=7.0)$ in 1919 and Edremit Gulf earthquake $(M=6.8)$ in 1944 (KOERI, 2017) as shown in Fig. 5b.

\section{Ground motions and response spectra}

An instrument situated in a low-rise appurtenant building adjacent to the local office of the Forestry Operation Directorate of Ayvacık, Çanakkale, recorded the shock as being $15-25 \mathrm{~km}$ away from the hypocenters. The acceleration components of three earthquakes recorded by this instrument are given in Fig. 6. As seen in this figure, the peak ground acceleration (PGA, i.e., $a_{\max }$ ) values are $70-110 \mathrm{~cm} \mathrm{~s}^{-2}$ in the north-south (N-S) direction, $70-90 \mathrm{~cm} \mathrm{~s}^{-2}$ in the east-west (E-W) direction and $20-30 \mathrm{~cm} \mathrm{~s}^{-2}$ in the vertical (U-D) direction for the shocks bigger than $M_{\mathrm{w}}=5$. According to earthquake zoning map of Turkey prepared by General Directorate of Disaster Affairs in 1996, the seismic zone of the city of Çanakkale is classified as 1 , where the probability of exceeding an effective PGA of $0.4 \mathrm{~g}$ is $10 \%$ in 50 years or the return period is 475 years (TEC, 2007). As can be seen in 


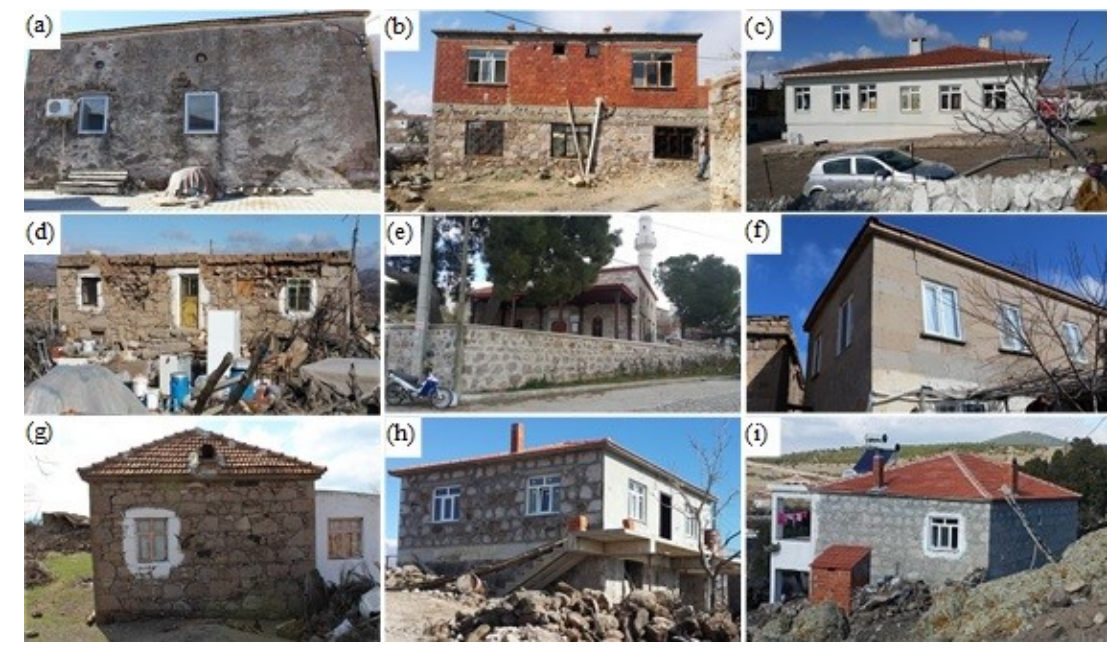

Figure 4. Existing building types in reconnaissance area: (a) hatıl dwelling (b) stone and brick with cement mortar, (c) engineered RC building (d) hatıl building with heavy roof, (e) historical masonry with cut stone, (f) cut stone without mortar, (g) stone without mortar, and $(h, i)$ stone with cement mortar and reinforced concrete.

Fig. 6, the peak value of acceleration was maximal in the $\mathrm{N}-$ $\mathrm{S}$ component and occurred as $110 \mathrm{~cm} \mathrm{~s}^{-2}$. It should be noted that PGA did not exceed the seismic hazard defined to be $0.4 \mathrm{~g}$ for this area in the seismic zone map of Turkey.

Response spectra with a damping ratio of 2 and $5 \%$ for horizontal components are computed and given in Fig. 7. This figure shows that the earthquake shaking would be most damaging to structures having a natural period of approximately up to $0.4 \mathrm{~s}$. The strong ground motion records, taken from Forestry Operation Directorate enabled us to determine the attenuation of the ground accelerations. The PGA from the five earthquakes was approximately $0.105 g$ at the station, which is $24 \mathrm{~km}$ away from the epicenter. Similarly, PGA was 0.03, 0.009 and $0.004 g$ at Ezine, Bozcaada and Bayramic stations, which are 31,33 and $48 \mathrm{~km}$ away from the epicenter, respectively.

The PGA values of Ayvacik records are indicated on the attenuation curve prepared by Gülkan and Kalkan (2002) for $M=5.5$ as shown in Fig. 8. The correlation of the observed data with the proposed empirical expression is very satisfactory. It should be noted that because the observed towns are approximately within $3-5 \mathrm{~km}$ distance to the epicenter of the earthquakes, the attenuation relationship shows that the damaged and collapsed buildings might have experienced 0.2 and $0.25 g$ PGA during the earthquakes for rock and soil site conditions, respectively. When elastic response spectra calculated by the earthquakes and attenuation is considered, the results show that the maximum acceleration exciting the buildings might reach a maximum of $0.25 \mathrm{~g}$ in the reconnaissance area. On the other hand, the damping ratio can reach a maximum of $5 \%$ for such masonry and adobe structures according to the Turkish Earthquake Code; however, design acceleration is given as $0.5 \mathrm{~g}$ in this region for masonry buildings. This comparison is the best evidence we have indicating that damaged or collapsed buildings did not receive any engineering service or were not built according to code in force at the time they were built.

\section{Evaluation of damage}

The damage was investigated in two separate subsections. In the first subsection, damage distribution according to affected villages and structures was addressed, while in the latter, damage modes and their technical causes were evaluated.

\subsection{Damage distribution}

Since the energy release was very small compared to the earthquakes that occurred on NAFZ or on EAFZ, the other highly active zones in Turkey, no reinforced concrete (RC) structures collapsed in the area other than the poorly constructed stone masonry dwellings in rural areas. According to the data obtained from Çanakkale Provincial Directorates of Environment and Urbanization, in 29 villages, there were about 2705 damaged or collapsed buildings out of 5790 structures, while 3083 structures did not suffer any damage. According to official estimates, within the affected area, a total of $1470(25 \%)$ structures (including apartments, houses, barns, offices, stores and haylofts) were heavily damaged or collapsed, and 1235 (22\%) structures suffered medium or minor repairable damage. Moreover, a total of $3083(53 \%)$ structures did not suffer any damage. The locations of 29 villages together with the epicenters of the studied earthquakes, their magnitudes and PGAs are given in Fig. 9, while the number of damaged structures and damage ratios within these villages are given in Figs. 10 and 11, respectively. It can be seen from Fig. 9 that Taşağ 1 l, Yukarıköy, Çamköy and Gülpınar are close to the epicen- 

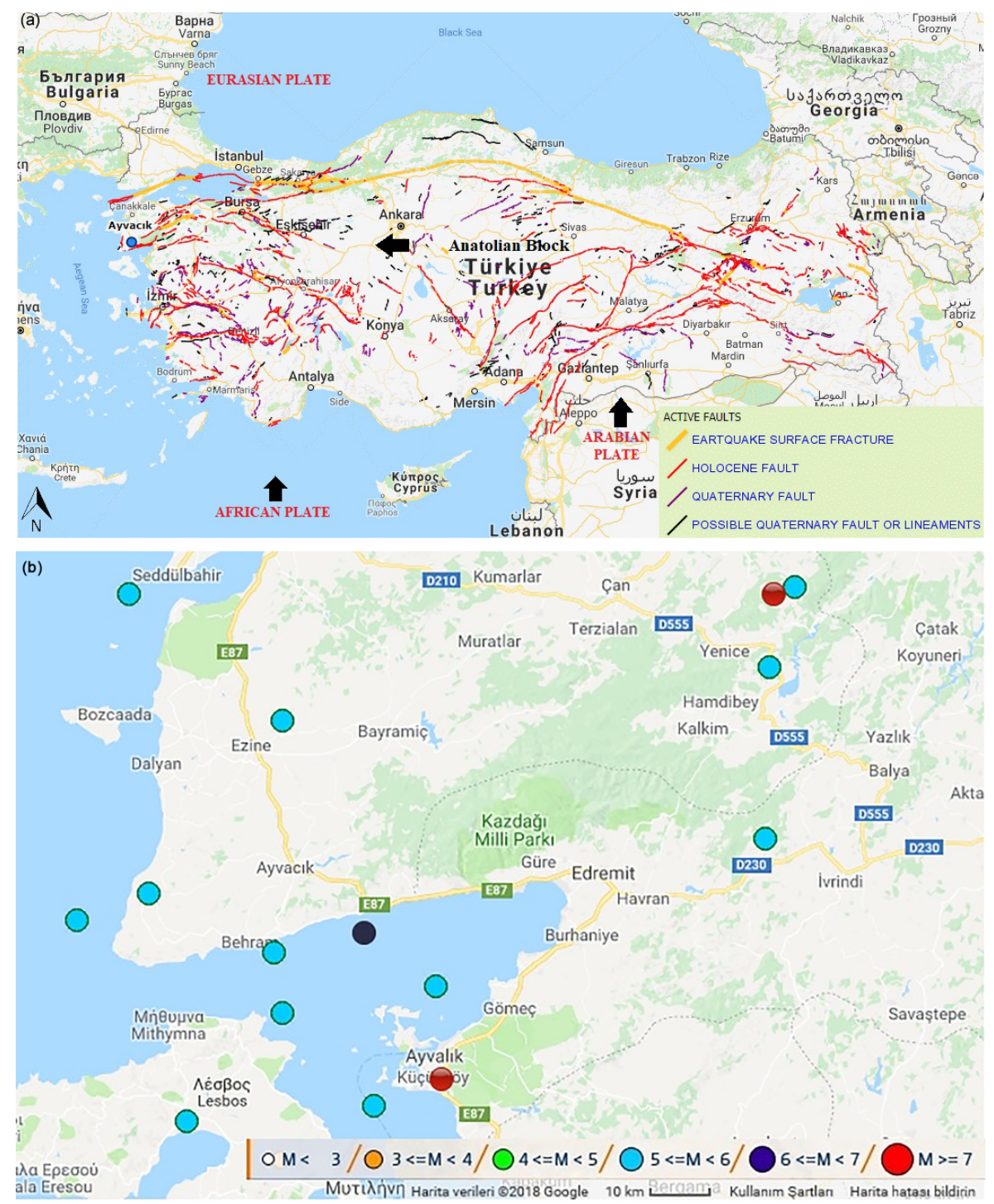

Figure 5. (a) Active fault map of Turkey (MRE, 2018). (b) The most powerful earthquake within the instrumental period around Ayvacik region (DEMP, 2017).

ters of earthquakes, although structures located in the town of Gülpınar experienced significantly less damage than other villages close to the epicenters (Fig. 11). These results may be related to the construction techniques and development level of Gülpınar, which are more advanced than the other villages.

Distribution maps of buildings in percentages according to damage levels are given in Figs. 12, 13 and 14, respectively. These figures clearly indicate that the percentage of heavily damaged/collapsed structures in Gülpınar was lower than in other villages close to the epicenters that suffered significant damage. The reason for this can be explained by Gülpınar being a historical center of the region, containing cultural heritage sites. The differences in terms of past experiences and development level between Gülpınar and other villages subsequently affect the quality of construction. Thus, structural damage was more prominent in the villages with relatively low economic development, and where there are no engineered buildings as observed by the authors.

Distribution maps mentioned above are created for damage ratios according to damage levels of all structures. However, evaluation of damage levels according to structure may introduce a new perspective in interpreting the damage. Additionally, such a parametric study may be a guide in order not to repeat similar mistakes when reconstructing structures which were likely to be heavily damaged or to have collapsed according to structure. Damage ratios according to six structures are generated in Fig. 15 with the support of Çanakkale Provincial Directorates of Environment and Urbanization. As can be seen from the figure, the construction practices ap- 

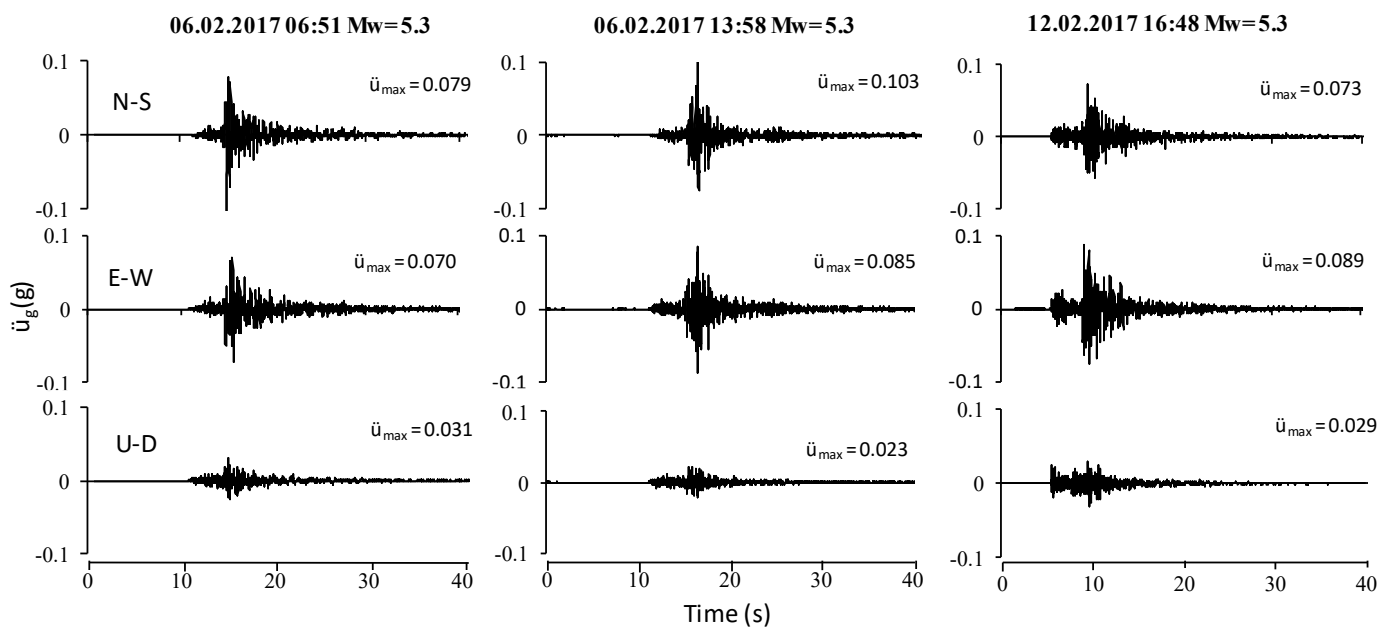

Figure 6. Three components of ground acceleration $\left(M_{\mathrm{W}}>5.2\right)$ of 6-24 February 2017 Ayvacık (Çanakkale) earthquakes.
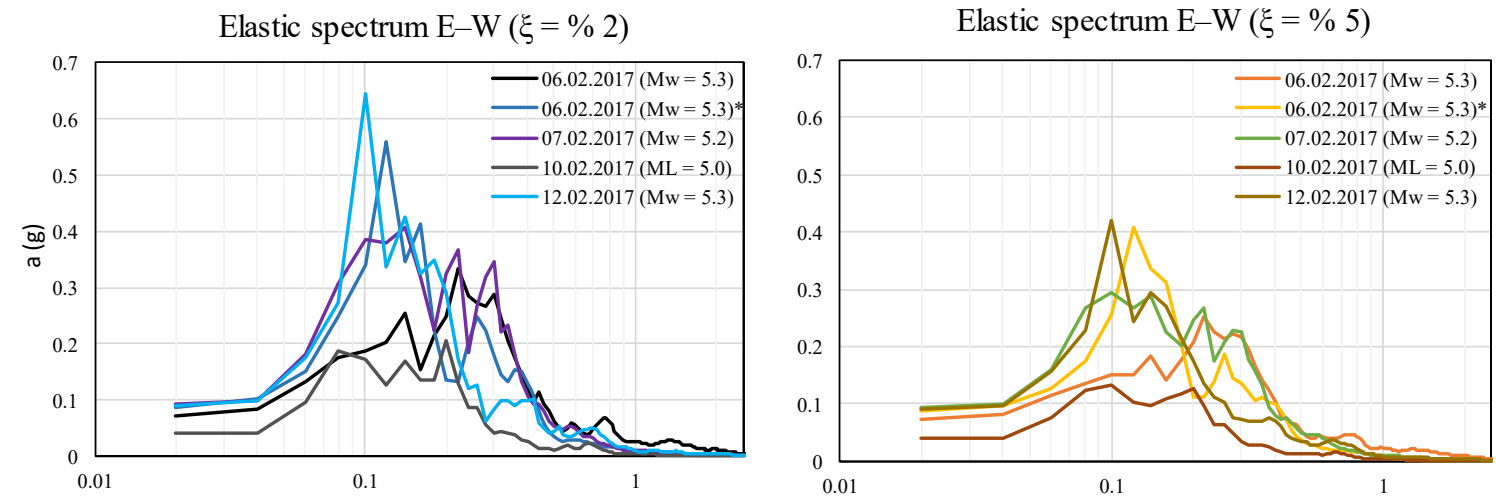

Elastic spectrum N-S $(\xi=\% 2)$
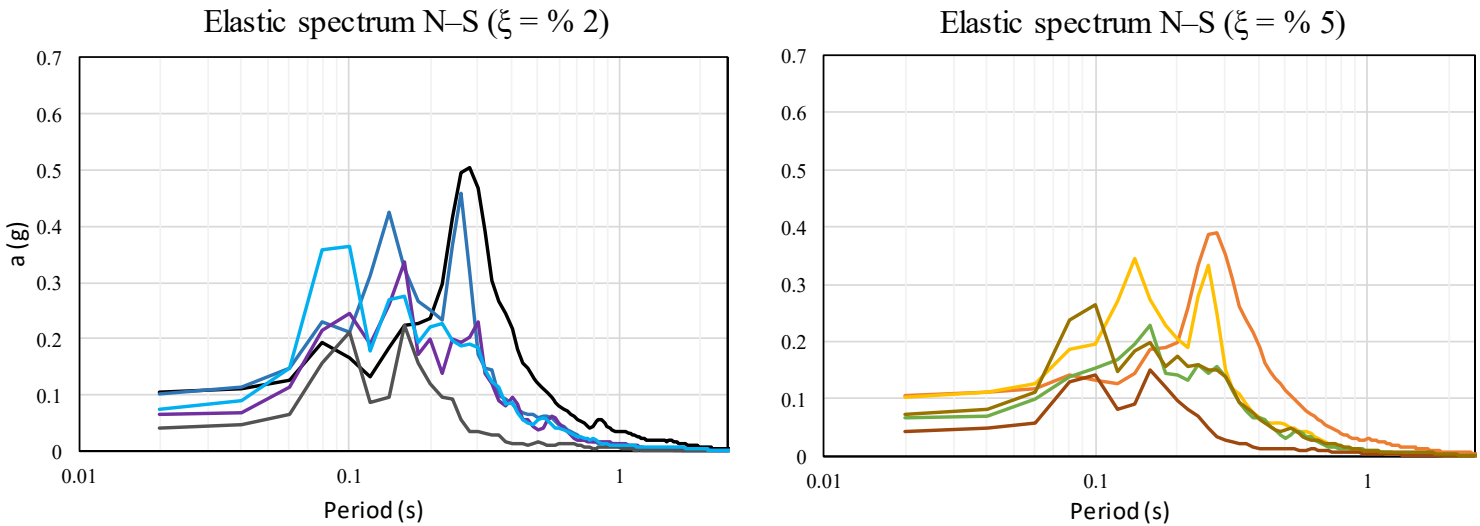

*This earthquake is the second earthquake that occurred in the same day having a magnitude of 5.3

Figure 7. Elastic acceleration response spectrums for N-S and E-W components of $\left(M_{\mathrm{W}}>5\right)$ of 6-24 February 2017 Ayvacık (Çanakkale) earthquake swarm. 

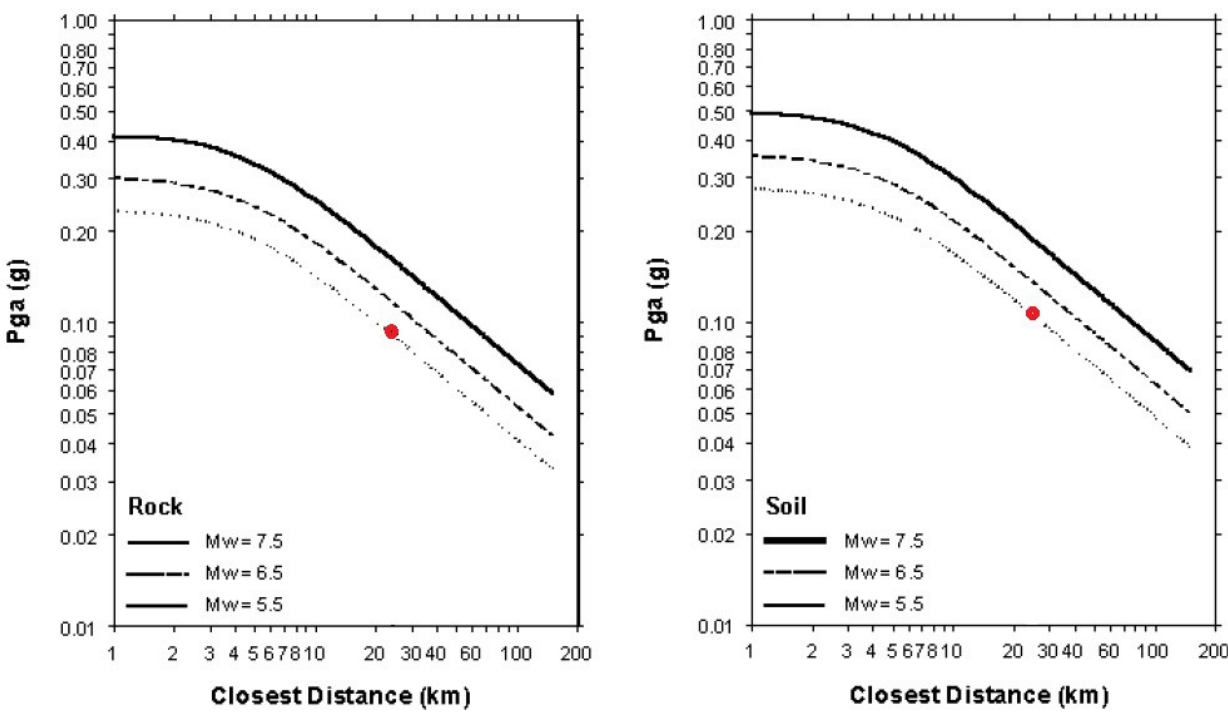

Figure 8. Curves of peak acceleration versus distance for magnitude 5.5, 6.5 and 7.5 earthquakes at rock and soft soil sites (Gülkan and Kalkan, 2002).

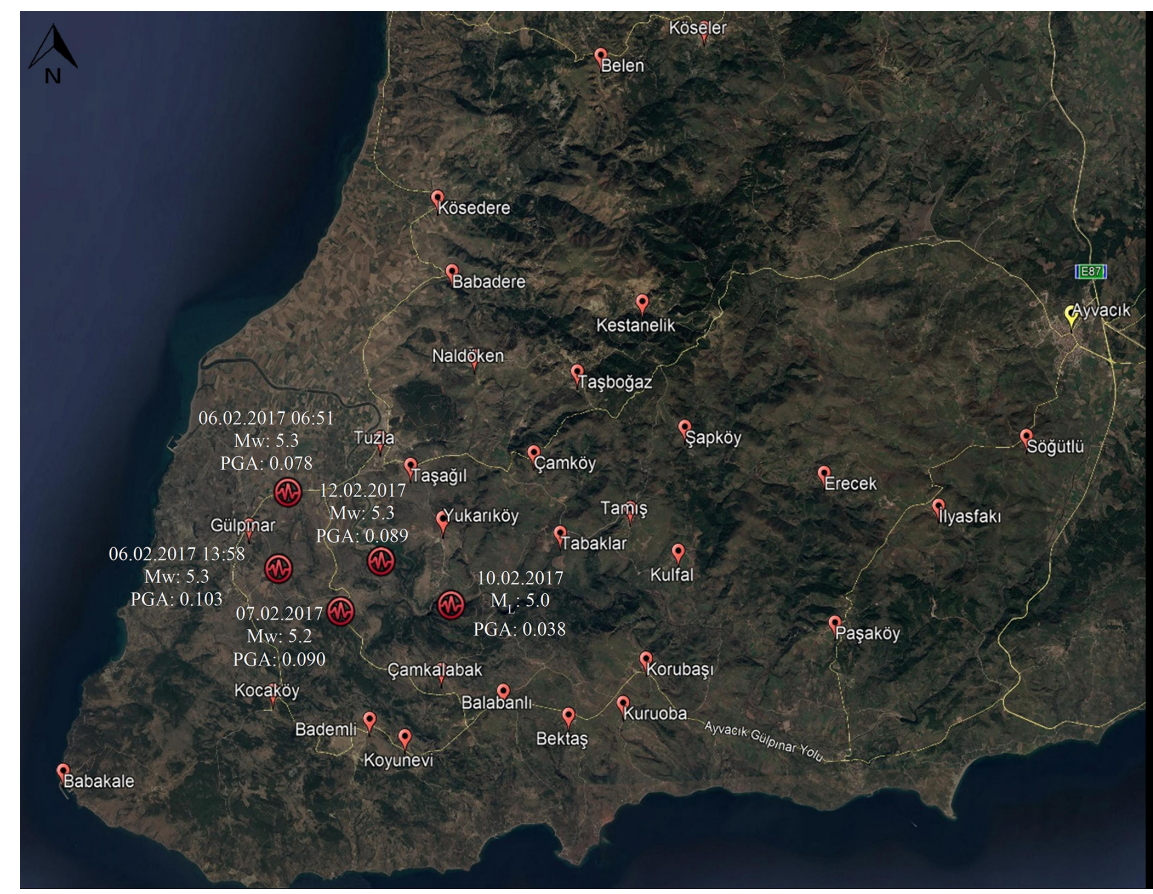

Figure 9. Villages affected by Ayvacık (Çanakkale) earthquake swarm and locations of investigated earthquakes.

plied on haylofts and barns should be substantially revised in order to minimize damage from a potential similar earthquake, because most haylofts and barns are constructed using stone without mortar, and because the net span between walls of the structures were high. On the other hand, the construction techniques for structures with a heavily damaged ratio of approximately $25 \%$, such as stores, houses and apartments can be reviewed and enhanced according to technical deficiencies mentioned in the next section. It can be seen that office structures experienced relatively less damage compared to other structures. Thus, it can be said that offices were constructed more in line with the conditions required by TEC 2007 .

\subsection{Damage profile}

Failure mechanisms observed during the 2017 Ayvacık (Çanakkale) earthquake swarm were also observed in 


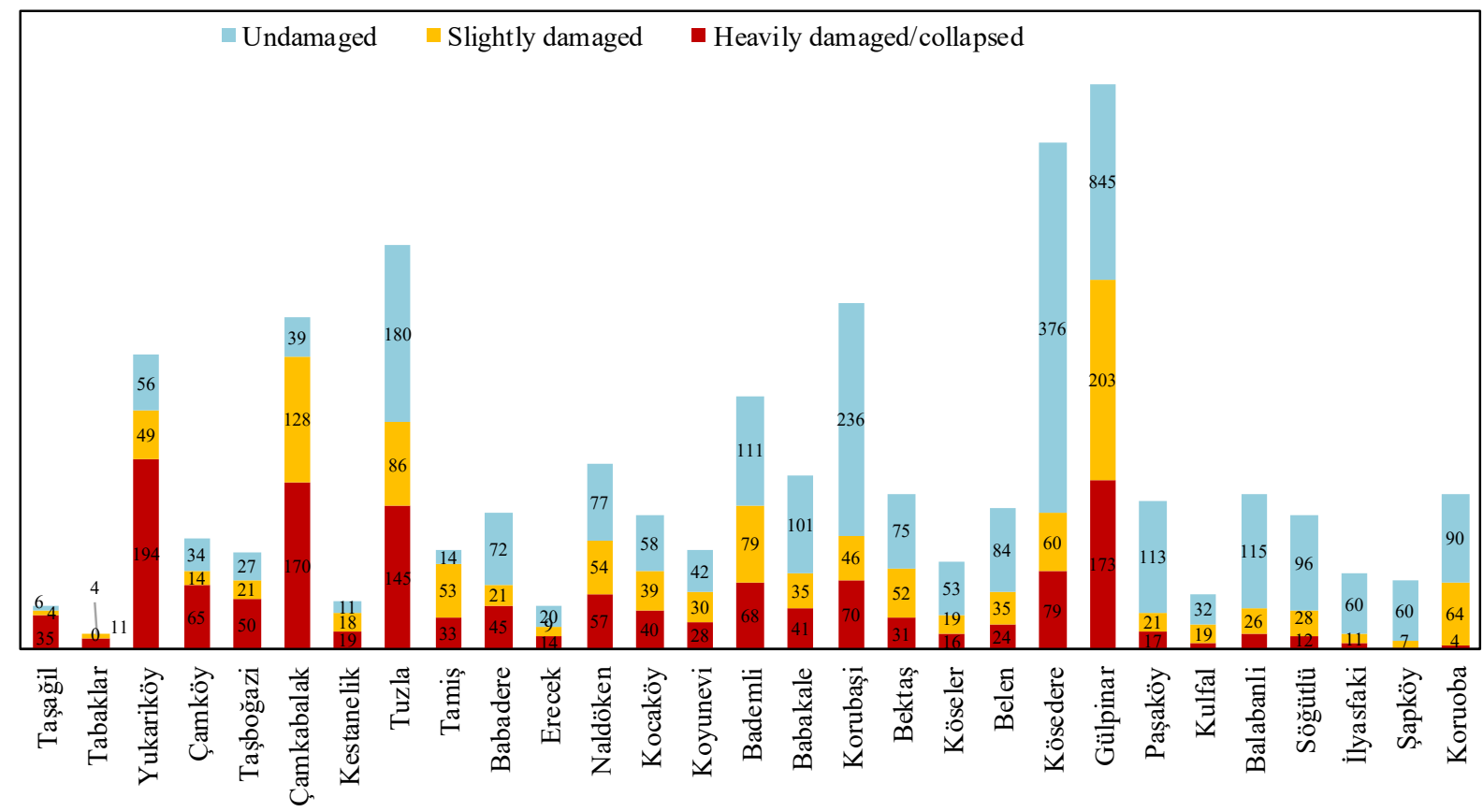

Figure 10. Number of buildings according to damage level due to Ayvacık (Çanakkale) earthquake swarm.

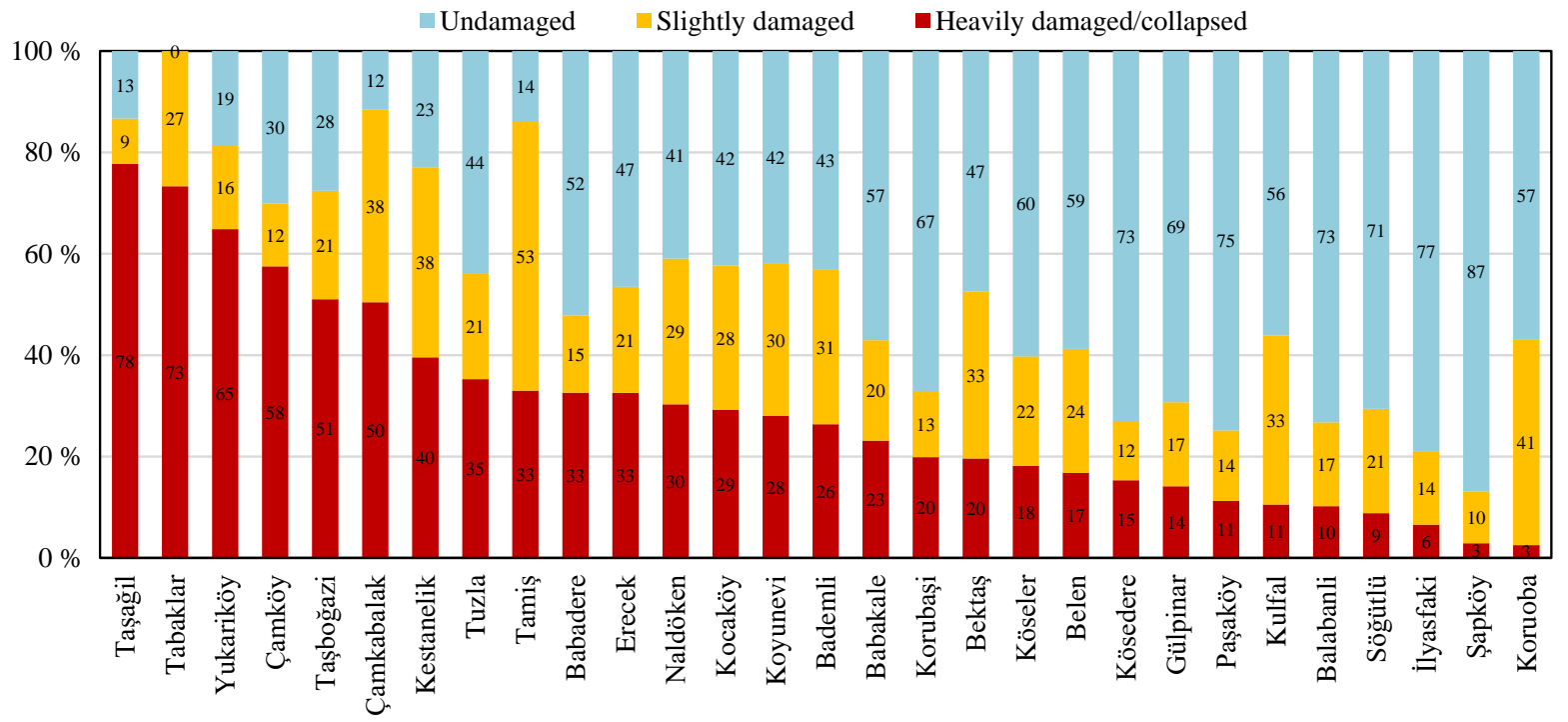

Figure 11. Damage ratios in villages according to damage level due to Ayvacık (Çanakkale) earthquake swarm.

other recent moderate earthquakes in Bala $\left(M_{\mathrm{L}}=5.5\right)$, Doğubeyazit $\left(M_{\mathrm{L}}=5.1\right)$, Dinar $\left(M_{\mathrm{L}}=5.9\right)$ and so on (Tezcan, 1996; Bayraktar et al., 2007; Adanur, 2010; Ural et al., 2012). Adanur (2010) showed that based on the investigations after the 20 and 27 December 2007 Bala (Ankara) earthquakes, masonry buildings were built in three types in the affected area: (1) stone masonry buildings with walls made of natural shaped stones, (2) stone masonry buildings with walls made of cut stones and (3) mixed ma- sonry buildings with walls made of masonry materials like stones and mud bricks, stones and bricks or stones and briquette. Overall, a total of 945 buildings were heavily damaged or collapsed in Bala. Bayraktar et al. (2007) reported that 1000 buildings were affected by the earthquake in Doğubeyazit. Similar to the above-mentioned studies, thus far, experiences from such moderate earthquakes in rural areas of Turkey have shown that even low-moderate earthquakes may cause significant damage to non-reinforced ma- 


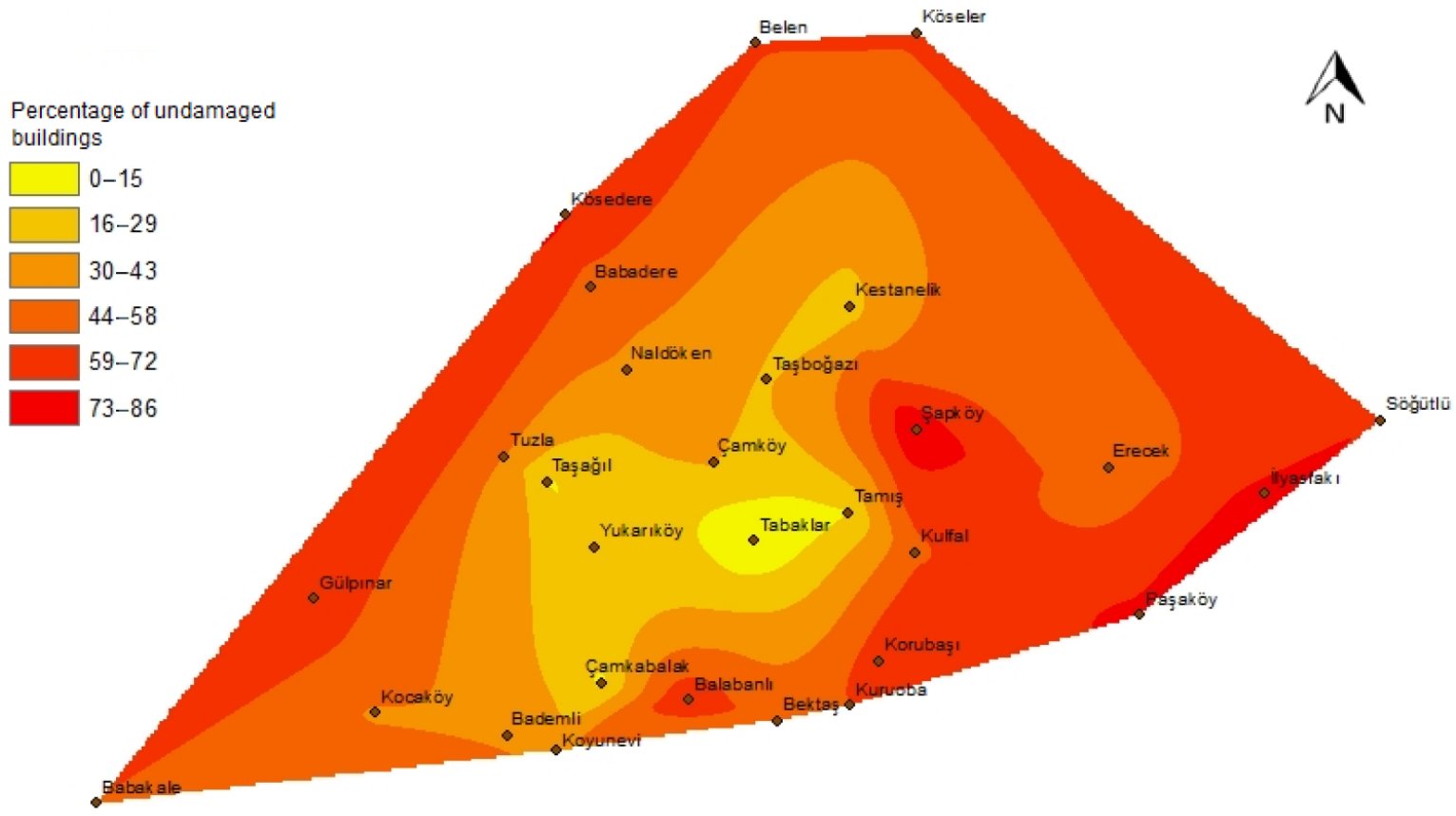

Figure 12. Distribution maps of undamaged buildings in percentage.

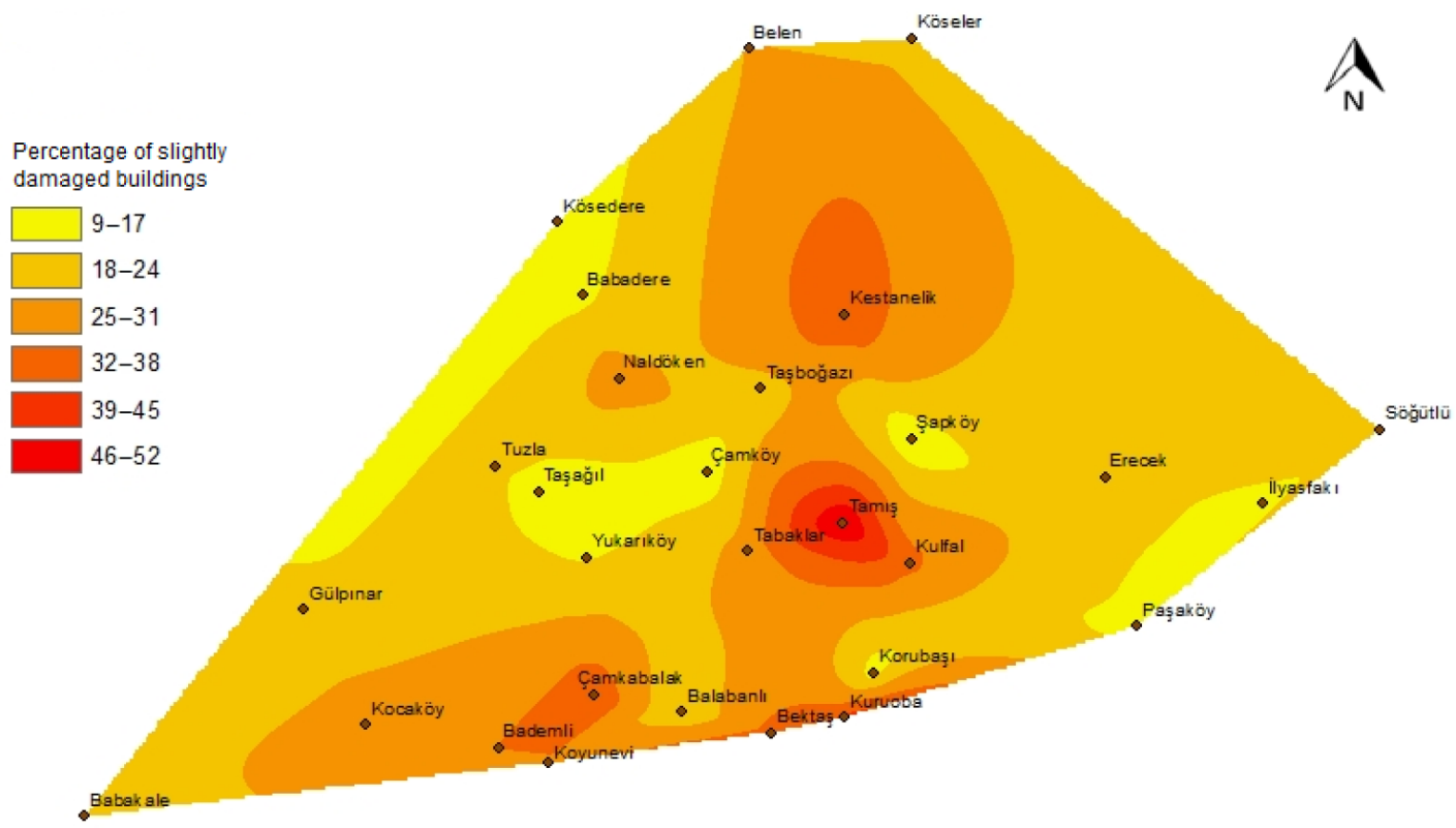

Figure 13. Distribution maps of slightly damaged buildings in percentage.

sonry structures (Fig. 16). This type of construction is among the most vulnerable type of building during an earthquake. Even under moderate lateral forces, such a masonry structure can be damaged or collapse due to lack of shear strength, improper interlocking mechanisms and/or poor stone-stone or stone-mortar bonding. In this case, shear failure is unavoid- able in the planes forming diagonal cracks along the wall due to workmanship defects. Furthermore, when the wall is not designed with any engineering in mind, catastrophic and rapid collapse occurs in out-of-plane bending mode. 


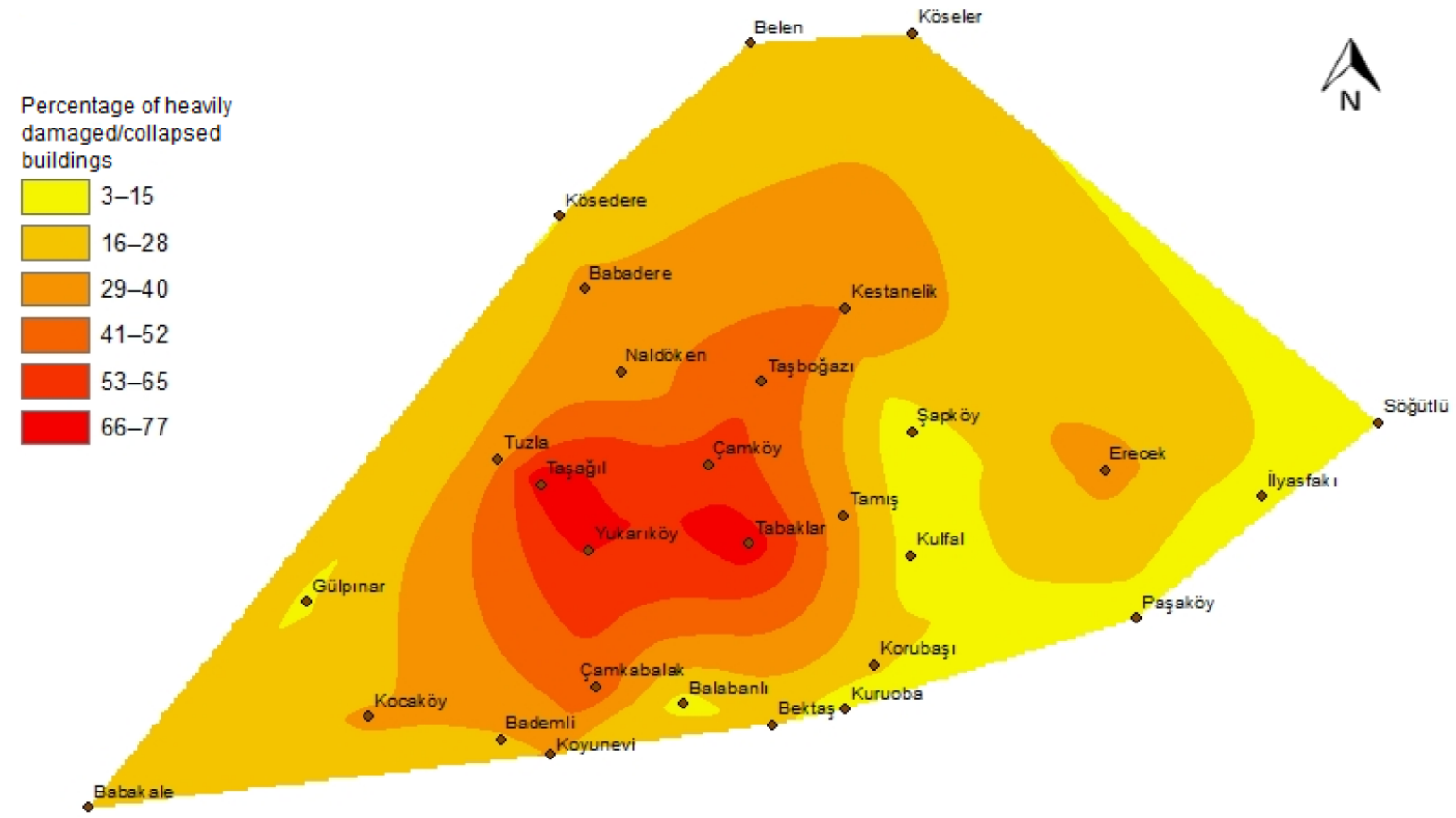

Figure 14. Distribution maps of heavily damaged/collapsed buildings in percentage.
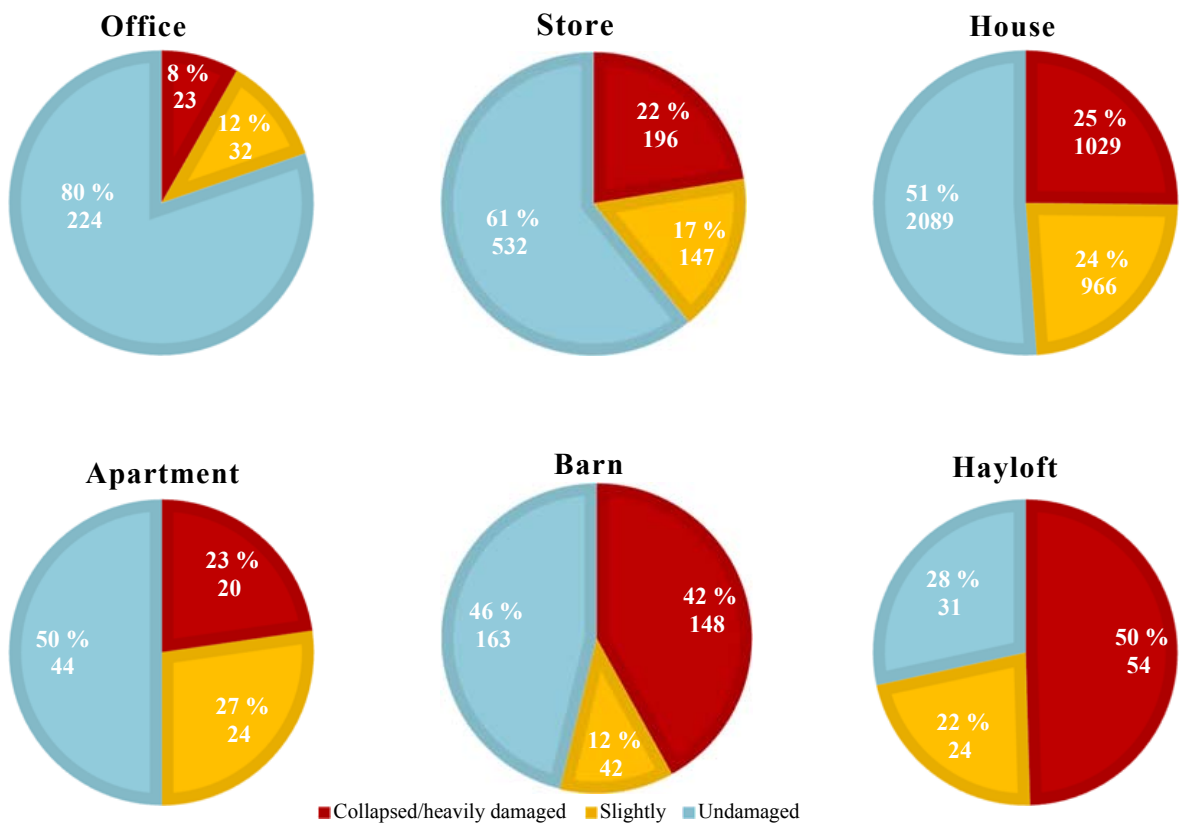

Figure 15. Damage ratios and levels according to structure.

In addition to the general failure mode mentioned above, the technical causes of damage and crashes observed in the reconnaissance area can be summarized as follows.

\subsubsection{Inadequate interlocking among the stones}

In rural areas of Turkey, the construction of dwellings is done by the owner-occupier with the help of craftsmen who live in the area but are not full-time builders. These builders often learn their trade through apprenticeship. Hence, they have their own tools and do not follow any technical rules on site; as a result, outdated and faulty construction techniques are maintained in a small region, and construction becomes highly similar between the dwellings. For example, during field observations, it was understood that even thick mor- 


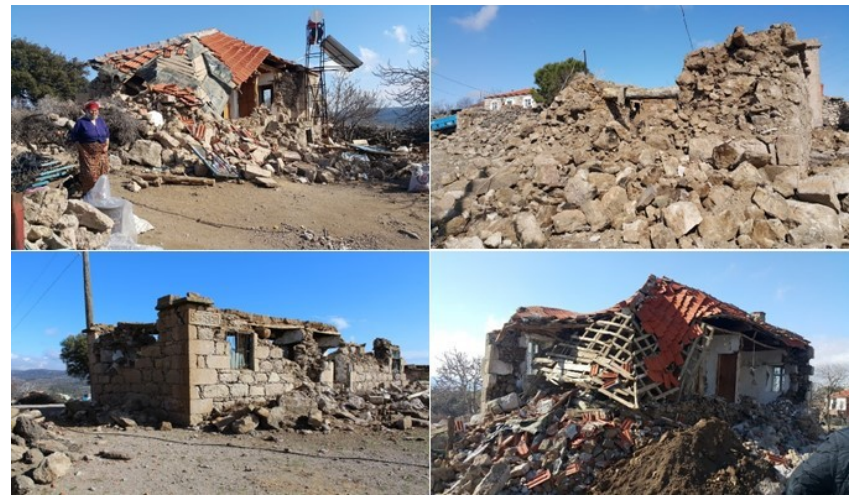

Figure 16. Examples of totally collapsed structures from Ayvacik (Çanakkale) 2017 earthquake swarm.

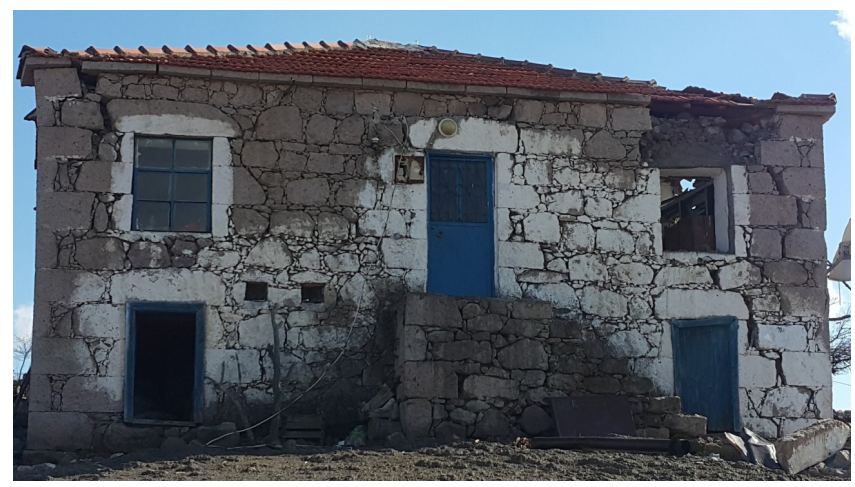

Figure 17. An example of a damaged dwelling due to inadequate interlocking.

tar or mud was not used as binding agent between stone or masonry units in almost all damaged houses. Figure 17 is a striking example of heavy damage during earthquakes due to lack of mortar among stones. After a few mild earthquakes this masonry dwelling became unstable.

Another damage type observed in the region is outward bulking of walls, which is caused by interlocking deficiency. The reason of this deficiency is the vertical gap between stones creating wall thickness as shown in Fig. 18. In order to prevent this damage, horizontal elements such as hatıl or key stone, which provide integrity to masonry walls, can be vertically used in specific intervals. The key stones or hatıl can provide limited resistance to lateral seismic loads, and thus probably prevent the out-of-plan failure in some parts of masonry walls.

Another interlocking damage type is observed at the intersection of perpendicular walls (Fig. 19). One of the walls acts out of plane while the other remains very stiff in plane, inevitably resulting in cracks. This type of damage can either result in gaps developing between the in-plane and out-ofplane wall or vertical cracks may occur in the out-of-plane wall (Tolles et al., 1996). Further stages of this damage may result in out-of-plane failure of the gable end wall. To avoid

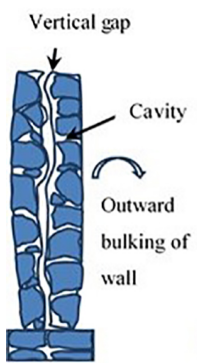

(a)

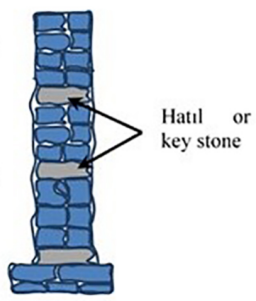

(b)

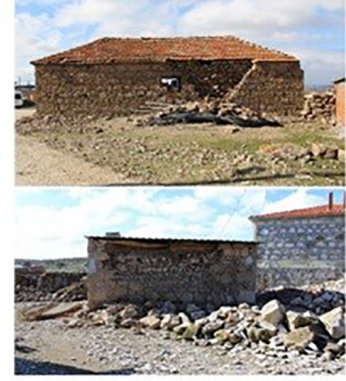

(c)
Figure 18. Schematics of (a) conventional wall section without through stone, (b) wall section with key stones (Sharma, 2016), (c) damage observed in the region.

intersection damage, the interlocking of the corners between perpendicular walls should be properly designed against lateral earthquake forces.

\subsubsection{Irregularly designed wall with cavity}

The design process of masonry buildings needs more regularity compared to other supporting systems, because resisting system must have continuity and regularity in order to take the stress of the shear from an earthquake. In rural areas, however, traditional fireplaces have been used in buildings, and they are built within the wall by decreasing the wall thickness or curving the wall outward. In such cases, irreversible damage is inflicted on the wall because of decreasing shear resistance (Fig. 20). This damage type was observed in different masonry structures on site. Different cases such as cut stone masonry, stone with plaster and stone without mortar can be seen in Fig. 20. The common damage type is most likely caused by the lack of craftsmanship or retention of traditional habits.

\subsubsection{Heavy earth roof}

Another important cause of damage is the roofs made from a thick and heavy layer of mud spread over wooden logs (Fig. 21). This technique is widely used in certain parts of Anatolia where timber is increasingly scarce. These heavy earth roofs are generally hardened by spreading soil with a cylindrical stone. The roof must be thickened more and more over the years to make it more durable against water leakage. Consequently, heavier roofs exert larger shear forces during an earthquake. In the investigated area, the roofs were either supported by beams and indirectly by walls or beams of the inner structure, and the columns were round or sub-round in cross section and the trunks were without bark. This made it virtually impossible to make strong connections and bearing surfaces between the beams. Such beams were prone to rolling over during motions induced by earthquakes. Moreover, the round ends of the beams exerted loads (to an ex- 


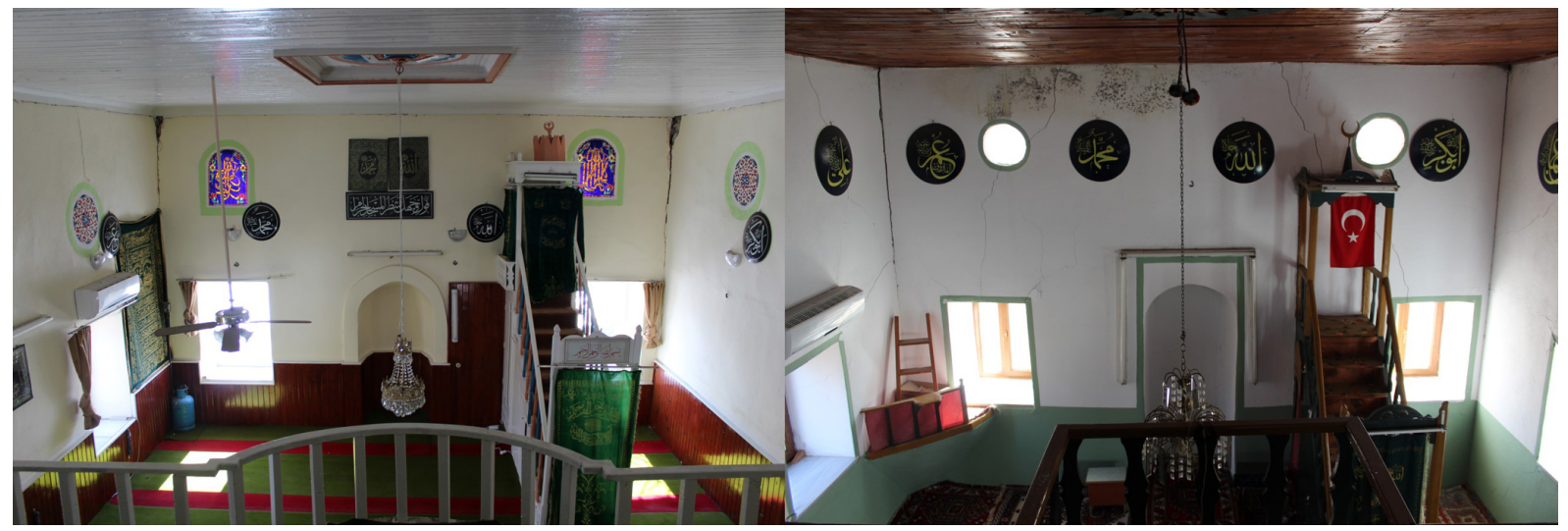

Figure 19. Observed damage at intersection of perpendicular walls.

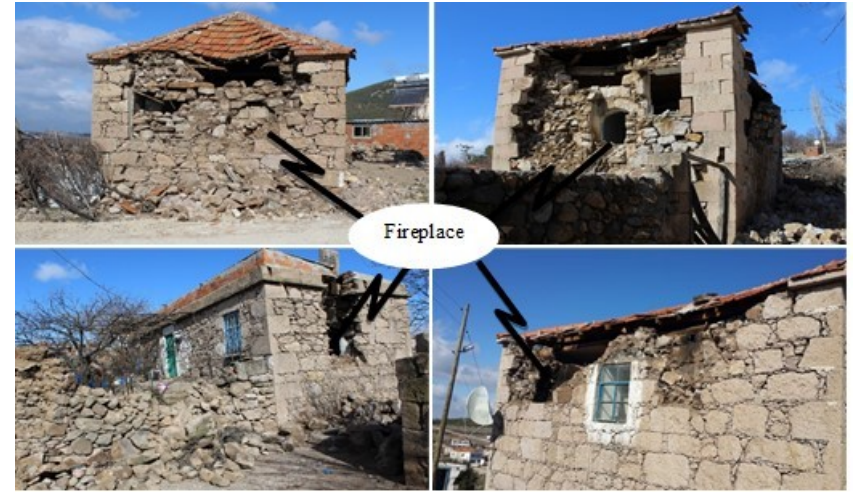

Figure 20. Examples of out-of-plane collapse due to wall cavity.

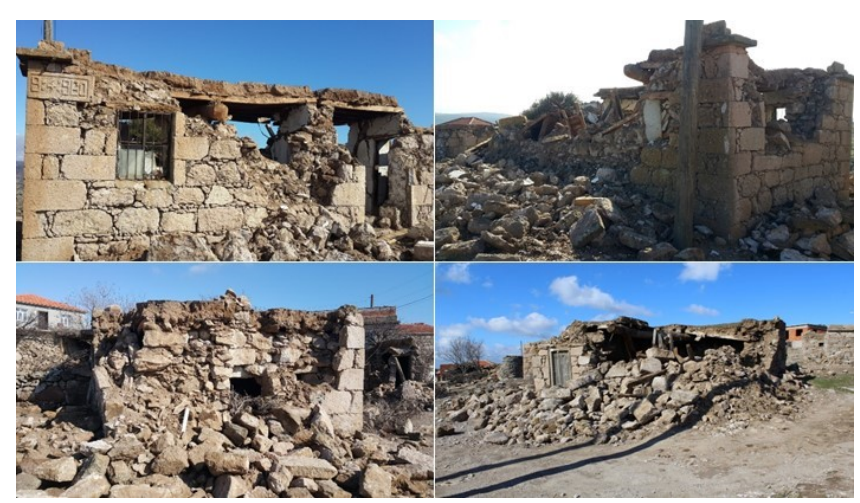

Figure 21. Examples of collapse due to heavy earth roof.

cessive degree) on the supporting walls beneath them, and resulted in the collapse of the earth roof or walls.

\subsubsection{Insufficient wall rigidities}

In many cases, distinctive diagonal or inclined cracks were observed in load-bearing window piers or walls with low width-to-height ratios as a result of inadequate shear resis-

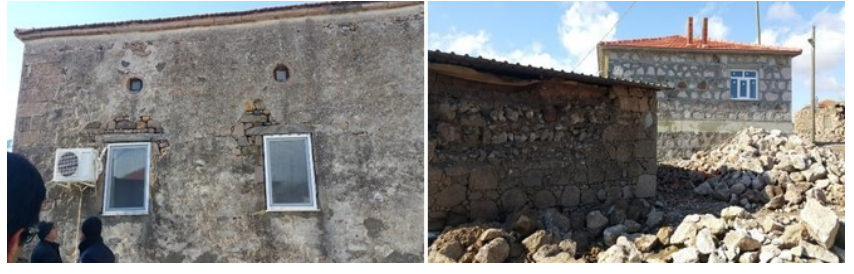

Figure 22. Examples of undamaged dwellings.

tance (Tomazevic, 1999). While bending and shear forces created by a moderate earthquake can be easily resisted by reinforced masonry with lateral and horizontal elements such as RC or timber (Fig. 22), the dwellings made from stone with no mortar cannot resist these forces. This construction defect causes in-plane failures by means of excessive shear force or bending or out-of-plane failure by bending depending on the aspect ratio of the unreinforced masonry elements.

Many weak masonry walls without mortar had diagonal or inclined shear cracking as a result of cyclic shear forces exerted during the earthquakes (Fig. 23). But this diagonal shear cracking does not necessarily lead to total collapse. However, collapse may be inevitable if the triangular wall blocks on each side of a full diagonal crack become unstable by substantially losing their interlock or friction resistance along the cracks (Fig. 24). Similar failures have previously been reported around the world (Ural et al., 2012; Klingner, 2006).

There were no industrial buildings within Ayvacik, and no damage was observed along highways or on bridges. There were no reported landslides or rock falls.

\section{Conclusions and recommendations}

The aim of this paper is (1) to evaluate the characteristics of earthquakes, (2) to scrutinize the damage distribution in terms of villages and structure types and (3) to investigate the damage and collapse mechanisms observed in buildings dur- 


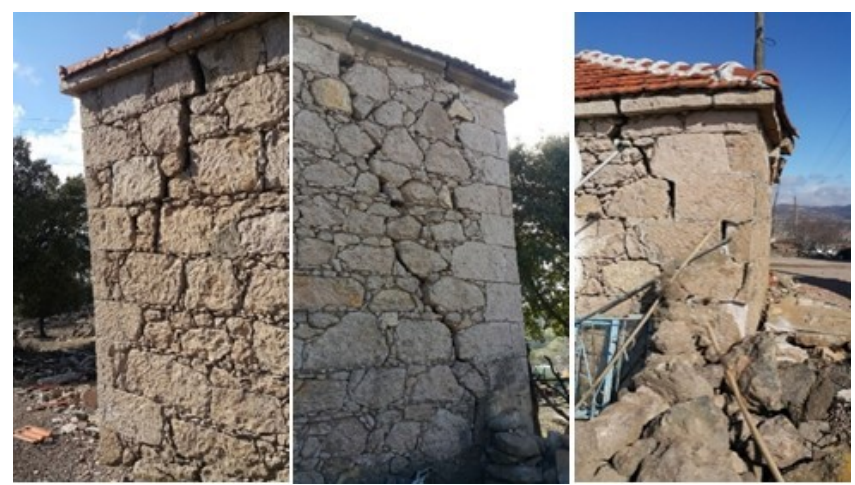

Figure 23. Examples of diagonal shear cracking.

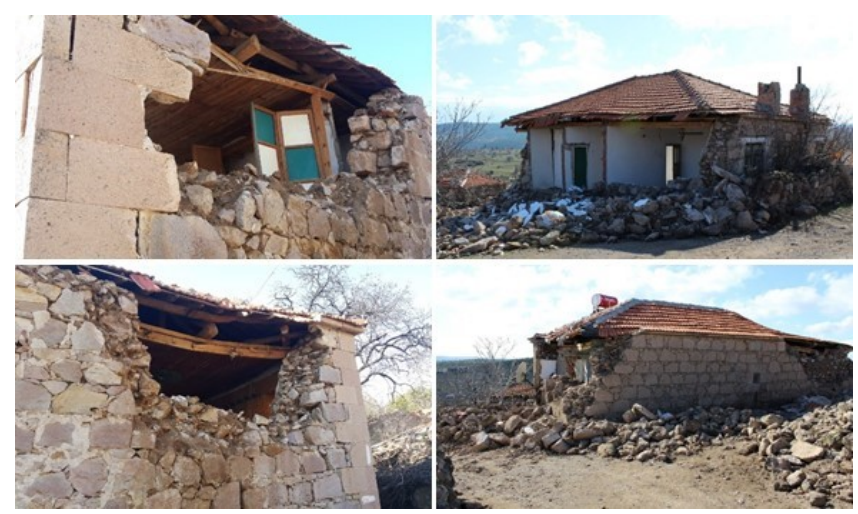

Figure 24. Out-of-plane failures due to improper wall thickness and/or height-length ratio.

ing a rare earthquake swarm that struck Ayvacık, Turkey, between 6 and 24 February 2017. This earthquake swarm contained almost 2000 earthquakes with some moderate earthquakes $\left(M_{\mathrm{w}}>5.0\right)$. The properties of these earthquakes with respect to civil engineering such as PGA and response spectrum were specified. Although the determined elastic spectrum remained under the design spectrum of TEC (2007), we observed significant damage and failure in many masonry structures in the reconnaissance area. The causes of the damage and construction failure observed in the survey can be explained as follows: (1) close proximity of damaged buildings to the epicenter of earthquakes, (2) influence of pre-existing cracks on the performance of buildings due to many earthquakes occurring in a short period of time, and (3) deficiency of construction process including poor workmanship and material quality, construction without any technical rule or code and lack of bonding or connection between structural elements. Also worth noting is that the damage distribution/ratio decreased as the distance from the epicenters of earthquakes increased, except for Gülpınar.

In conclusion, the authors have some opinions/recommendations about damaged structures in the affected region and structures in other rural regions located in seismic hazard areas. (a) The authors recommend that the construction practices (such as using stone without mortar) commonly used in the affected region, which allowed for damage and resulted in the structural failure of buildings, should be avoided. In addition, new structures in the region must be constructed according to TEC 2007. (b) It is rather hard to find an available retrofitting technique for such heavy structures that has no connections between its elements. Even if one or more retrofitting techniques could be applied to the structure, the cost of retrofitting such structures would possibly be higher than new construction. Thus, retrofitting these damaged structures may not be logical and economical according to authors' observations. (c) The findings in this study indicate that the urban transformation started in the cities of Turkey due to seismic risk is also necessary in rural regions, especially in highly seismic zones.

Data availability. Data of Figs. 1, 2, 5 and 6 are publicly available (http://www.deprem.gov.tr/depremdokumanlari/1495, DEMP, 2017), while other data are not publicly available.

Competing interests. The authors declare that they have no conflict of interest.

Special issue statement. This article is part of the special issue "Damage of natural hazards: assessment and mitigation". It is not associated with a conference.

Acknowledgements. We thank the Çanakkale Provincial Directorates of Environment and Urbanization for sharing the damage data of the villages, and also appreciate the sincere contribution of Uğur Avdan from Anadolu University in preparing the distribution maps of damage ratios.

Edited by: Daniela Molinari

Reviewed by: Seda Kundak and one anonymous referee

\section{References}

Adanur, S.: Performance of masonry buildings during the 20 and 27 December 2007 Bala (Ankara) earthquakes in Turkey, Nat. Hazards Earth Syst. Sci., 10, 2547-2556, https://doi.org/10.5194/nhess-10-2547-2010, 2010.

Bayraktar, A., Coşkun N., and Yalçin A.: Damages of masonry buildings during the 2 July 2004 Doğubayazıt (A ğrı) earthquake in Turkey, Eng. Fail. Anal., 14, 147-157, https://doi.org/10.1016/j.engfailanal.2005.11.011, 2007.

Bozkurt, E.: Neotectonics of Turkey - a synthesis, Geodin. Acta., 14, 3-30, https://doi.org/10.1016/S0985-3111(01)01066X, 2001.

DEMP, Ayvacık-Çanakkale Earthquake Report, Republic of Turkey Prime Ministry Disaster and Emergency Management Presi- 
dency, Ankara, Turkey, available at: http://www.deprem.gov.tr/ depremdokumanlari/1495, last access: 12 February 2017.

Emre, Ö., Duman, T. Y., Özalp, S., Elmacı, H., Olgun, Ş., and Şaroğlu, F.: Active Fault Map of Turkey with and Explanatory Text, General Directorate of Mineral Research and Exploration, Special Publication Series-30, Ankara-Turkey, available at: http://www.mta.gov.tr/eng/maps/active-fault-1250000, last access: 13 March 2018.

Gülkan, P. and Kalkan, E.: Attenuation modeling of recent earthquakes in Turkey, J. Seismol., 6, 397-409, https://doi.org/10.1023/A:1020087426440, 2002.

Gürer, A. and Bayrak, M.: Relation between electrical resistivity and earthquake generation in the crust of West Anatolia, Turkey, Tectonophysics, 445, 49-65, https://doi.org/10.1016/j.tecto.2007.06.009, 2007.

Hughes, R. Hatil Construction in Turkey, Earthquake-safe: lessons to be learned from traditional construction, International Conference on the Seismic Performance of Traditional Buildings, Istanbul, Turkey, 1-9, available at: https://www.researchgate.net/ publication/268181745_Hatil_Construction_in_Turkey (last access: 13 March 2018), 2000.

KOERI: Gülpınar-Ayvacık (Çanakkale) earthquake report, Kandilli Observatory and Earthquake Research Institute, İstanbul, Turkey, 6-24 February 2017, 2017.

Klingner, R. E.: Behavior of masonry in the Northridge (US) and Tecomán-Colima (Mexico) earthquakes: Lessons learned, and changes in US design provisions, Constr. Build. Mater., 20, 209219, https://doi.org/10.1016/j.conbuildmat.2005.08.024, 2006.
MRE: General Directorate of Mineral Research and Exploration, available at: http://yerbilimleri.mta.gov.tr/anasayfa.aspx, last access: 12 March 2018.

Sharma, K., Deng, L., and Noguez, C. C.: Review article: Field investigation on the performance of building structures during the 25 April 2015, Gorkha earthquake in Nepal, Eng. Struct., 121 , 61-74, https://doi.org/10.1016/j.engstruct.2016.04.043, 2016.

TEC: Specification for structures to be built in seismic zones, Ministry of Public Works and Settlement Government of Republic of Turkey, Turkey, 156, 2007.

Tezcan, S. and Ipek, M.: A reconnaissance report: 1995 Dinar, Turkey, earthquake, Eng. Struct., 18, 906-916, https://doi.org/10.1016/0141-0296(95)00219-7, 1996.

Tolles, E. L., Webster, F. A., Crosby, A., and Kimbro, E. E.: Survey of damage to historic adobe buildings after the January 1994 Northridge earthquake, Getty Conservation Institute, USA, 28, available at: https://www.getty.edu/conservation/publications_ resources/pdf_publications/pdf/adobe_northridge.pdf (last access: 20 March 2018), 1996.

Tomaževič, M.: Earthquake-resistant Design of Masonry Buildings, Imperial College Press, London, UK, 265, 1999.

Ural, A., Dogangün, A., Sezen, H., and Angin, Z.: Seismic performance of masonry buildings during the 2007 Bala, Turkey earthquakes, Nat. Hazards, 60, 1013-1026, https://doi.org/10.1007/s11069-011-9887-4, 2012. 